\title{
A Review on Tumor Heterogeneity and Evolution in Multiple Myeloma: Pathological, Radiological, Molecular Genetic, and Clinical Integration
}

Christian M. Schürch ${ }^{1}$, Leo Rasche ${ }^{2}$, Leonie Frauenfeld ${ }^{3}$, Niels Weinhold ${ }^{4}$, Falko Fend ${ }^{3}$

${ }^{1}$ Department of Microbiology and Immunology, Stanford University School of Medicine, Stanford, CA, USA

${ }^{2}$ Department of Internal Medicine II, University Hospital Würzburg, Würzburg, Germany

${ }^{3}$ Institute of Pathology and Neuropathology and Comprehensive Cancer Center, University Hospital Tübingen, Tübingen, Germany

${ }^{4}$ Department of Internal Medicine V, University of Heidelberg, Heidelberg, Germany

\section{Correspondence}

Falko Fend, Institute of Pathology and Neuropathology, University Hospital Tübingen, Liebermeisterstrasse 8, 72076 Tübingen, Germany;

Telephone: +49707129802 07; Fax: +497071292258

E-Mail: falko.fend@med.uni-tuebingen.de

\section{ORCID}

Christian M. Schürch: 0000-0002-1792-1768

Leo Rasche: 0000-0002-9536-9649

Falko Fend: 0000-0002-5496-293X

Word count (excluding abstract, references, legends): 4277

\section{Keywords}

Multiple myeloma; personalized medicine; plasma cell neoplasms; review; tumor evolution; tumor heterogeneity 
Schürch et al.

\begin{abstract}
Recent research has dramatically advanced our understanding of the genetic basis of multiple myeloma (MM). MM displays enormous inter- and intratumoral heterogeneity, and underlies a clonal evolutionary process driven and shaped by diverse factors such as clonal competition, tumor microenvironment, host immunity, and therapy.
\end{abstract}

Two main cytogenetic groups are distinguished: $\mathrm{MM}$ with recurrent translocations involving the immunoglobulin heavy chain locus, and MM with hyperdiploidy involving the odd chromosomes. The disease virtually always starts with a preneoplastic prodromal phase monoclonal gammopathy of undetermined significance - that variably progresses to symptomatic MM within a few months or many years. Tumor heterogeneity and its evolution in space and time have important consequences for the clinical management and outcome of MM patients. At diagnosis, spatial intratumoral heterogeneity poses a challenge for classification and risk stratification. During maintenance therapy, clonal evolution may complicate disease monitoring and promote drug resistance. Upon progression or transformation, identifying the dominant disease-driving neoplastic clones and elucidating their properties are key to tailor personalized therapy.

In this review, we discuss tumor heterogeneity and clonal evolution in MM, integrating pathological, radiological, molecular genetic, and clinical data. Current and prospective classification schemes and prognostic parameters, incorporating new genetic and proteomic discoveries and advances in imaging, are highlighted. In addition, the roles of the tumor microenvironment, host immunity, and resistance mutations, and their effects on therapy, are discussed.

An improved understanding of high-risk disease, tumor heterogeneity, and clonal evolution will guide future therapies and may ultimately lead towards a cure for MM. 
Schürch et al.

\section{Introduction}

Plasma cell neoplasms (PCNs) arise from terminally differentiated antibody-producing B cells and evolve through a chain of genetic events from the indolent, pre-malignant disorder monoclonal gammopathy of undetermined significance (MGUS) to multiple myeloma (MM) and its end-stage variants. $\mathrm{MM}$ is the second most common hematological malignancy, affecting $>90,000$ individuals in the United States and representing $1.6 \%$ of all cancers [1]. The clinical behavior of MM and other advanced PCNs is very heterogeneous, with survival rates ranging from months to decades [2]. This heterogeneity can be attributed to tumor genetics and epigenetics, as well as a range of extrinsic factors including the tumor microenvironment (TME), disease stage, and host immune response [3-9]. The diagnosis and classification of PCNs is based on integration of clinical, serological, pathological, radiological, and molecular genetic findings. PCNs are categorized as precursor lesions, i.e. MGUS and smoldering MM (SMM); solitary plasmacytoma with osseous or extraosseous localization, standard-risk MM, and high-risk disease including advanced and relapsed/refractory (R/R) MM [10]. Furthermore, in the WHO classification, specific subtypes of PCNs are recognized based on their predominant clinical symptoms, such as AL amyloidosis; their association with specific syndromes, such as POEMS (Polyneuropathy, Organomegaly, Endocrinopathy, Monoclonal gammopathy and Skin changes); or their anatomic location, as for extramedullary plasmacytoma (EMP) and plasma cell leukemia (PCL).

New treatment strategies including proteasome-targeting drugs, monoclonal antibodies (mAbs), immunomodulators and autologous hematopoietic stem cell transplantation (autotransplant) have induced long-term remissions and improved the outcomes of many MM patients. On average, fit elderly patients have a median overall survival (OS) of 5 years, and OS in younger patients receiving auto-transplant approaches 10 years [11]. However, for the $20-30 \%$ of MM patients with high-risk disease, even the most intensive therapies have not resulted in satisfactory outcomes $[10,12]$. In these patients, tumor heterogeneity and clonal 
Schürch et al.

evolution of MM under therapy favor the emergence of resistant clones that lose their dependence on the bone marrow (BM) microenvironment, ultimately relapsing as end-stage EMD or PCL [10]. Therefore, identifying high-risk patients and treating them accordingly is key to improve global outcomes in MM. This can be achieved by correct interpretation and integration of diagnostic findings from multiple clinical disciplines, including pathology, radiology and clinical genomics.

Recent sequencing efforts have shed light on the mutational landscape of PCNs and have unraveled a complex picture of initiation, evolution, and progression of these diseases, leading to inter- and intratumoral heterogeneity (Figure 1). Combining advanced medical imaging modalities with targeted biopsies and genetic investigation has provided insights into spatial intratumoral heterogeneity and regional genetic variation, uncovering the primary existence - or drug-induced emergence - of high-risk, disease-driving subclones that determine prognosis. These findings have raised new challenges for PCNs with regard to initial diagnosis and classification, as well as for follow-up protocols under therapy [10], and raise the following important questions: (1) What practical impact have pathological and genetic heterogeneity and clonal evolution on the clinical management of patients with PCN? (2) What is the role of advanced imaging modalities, i.e. diffusion-weighted magnetic resonance imaging (DW-MRI) and ${ }^{18}$ fluoro-deoxyglucose positron emission tomography / computed tomography (FDG$\mathrm{PET} / \mathrm{CT}$ ) in routine PCN diagnosis and follow-up? (3) How does tumor heterogeneity as seen in these imaging modalities, such as large focal lesions (FLs) or EMD, influence downstream diagnostic procedures including guided lesion biopsies and extended sequencing? (4) What is the best way to integrate pathological, radiological and genetic findings (e.g. from multiple heterogeneous lesions), and what is their impact on prognosis and prediction of therapy response? 
Schürch et al.

In this review, we will address these questions from a multidisciplinary point of view, integrating current knowledge on the biology, pathology, genetics, imaging, and clinical features of PCNs with a special focus on the impact of tumor heterogeneity.

\section{Heterogeneity at the pathological level}

According to the Revised 2017 WHO Classification of Tumors of Hematopoietic and Lymphoid Tissues, PCNs are subdivided into 5 categories: (1) non-IgM MGUS; (2) plasma cell myeloma/MM, (3) solitary plasmacytoma; (4) monoclonal immunoglobulin (Ig) deposition disease; and (5) PCNs with associated paraneoplastic syndrome [13]. Trephine BM biopsies and aspirates continue to be pivotal for a correct diagnosis of PCNs. BM aspirates are often helpful to assess cytological abnormalities, but can sometimes be negative for plasma cells due to the heterogeneous distribution in the BM. Sheets of malignant plasma cells displaying cellular and nuclear atypia including multinucleation and prominent nucleoli, in combination with positivity for CD138, light chain restriction, and aberrant expression of CD56 in immunohistochemistry (IHC), render the diagnosis of MM. However, early cases with low percentages of neoplastic plasma cells are more challenging, and a diagnosis of MM requires the integration of clinical features, especially the presence or absence of CRAB criteria (hyperCalcemia, Renal insufficiency, Anemia and Bone lesions) (Table 1). In these early stages, morphological findings such as the dissociation of groups of plasma cells from their usual perivascular $\mathrm{BM}$ niche or signs of active bone resorption can provide a hint at the diagnosis. Prominent nucleoli, intracytoplasmic and intranuclear immunoglobulin inclusions (Russell bodies, Dutcher bodies, respectively) and deposits in macrophages (Gaucher-like cells or crystalline inclusions, respectively) may point to malignancy but may also be found in reactive processes and are therefore not specific. In addition to their diagnostic utility, morphology and IHC deliver valuable information with regards to potential biological and molecular genetic mechanisms driving the PCN. For example, MM with lymphoplasmacytoid 
Schürch et al.

morphology is frequently associated with $\mathrm{t}(11 ; 14)(\mathrm{q} 13 ; \mathrm{q} 32)$ translocation, exhibits staining for cyclin D1 in IHC and is commonly CD20-positive, potentially even resulting in a misdiagnosis of mantle cell lymphoma [14, 15] (Figure 2). Strong and homogeneous nuclear cyclin D1 positivity can be taken as a surrogate for the presence of a $\mathrm{t}(11 ; 14)$ translocation, whereas more heterogeneous and weaker reactivity is observed mainly in cases with trisomy 11 [15]. In MGUS, cyclin D1 expression in plasma cells can confirm the presence of a clonal proliferation. Rare heavy chain isotypes are also associated with specific features; e.g. $20 \%$ of PCNs with lymphoplasmacytoid morphology are IgD-producing, whereas the rare IgM-producing MM shows conventional morphology and is CD20-negative, despite containing the $\mathrm{t}(11 ; 14)$ translocation in $>80 \%$ of cases [16-18]. Further cytomorphological features include mature, intermediate, immature and plasmablastic morphology, the latter associated with significantly worse prognosis and common $M Y C$ translocations, which usually represent a secondary genetic event in MM. Of note, plasmablasts and plasmablastic myeloma have been defined by different criteria cytologically (i.e., in the BM aspirate) and histologically (i.e. in the BM trephine biopsy) [18-20]. Cytologically, Greipp et al. defined plasmablasts as having a large central nucleus $(>10$ $\mu \mathrm{m}$ diameter) or a large nucleolus and scant cytoplasm; for a diagnosis of plasmablastic myeloma, plasmablasts needed to constitute $\geq 2 \%$ of nucleated marrow cells in the aspirate. In contrast, Bartl et al. characterized plasmablastic myeloma as having a majority of cells with immunoblast-like features with prominent central nucleoli and rather scant cytoplasm in the BM trephine. Irrespective of these different diagnostic criteria, plasmablastic myeloma usually accounts for $5-15 \%$ of $\mathrm{MM}$ cases and shows aggressive behavior.

The phenotype and phenotypic variability of malignant plasma cells is also exploited in flow cytometry, which is a mainstay in the diagnostic evaluation and especially minimal residual disease detection of MM. In addition, the antigen profile of clonal plasma cells has been used for prognostic purposes and for risk assessment in MGUS and SMM [21-25]. 
Schürch et al.

Another aspect of heterogeneity at the pathological level are solitary plasmacytomas, accounting for about $6-10 \%$ of all PCNs, which manifest either as solitary osteolytic lesion or as a tumoral proliferation in an extramedullary location, mostly mucosal sites in the head and neck region, less commonly in lymph nodes. Although extramedullary plasmacytomas (EMPs) by definition do not show BM involvement, sensitive techniques can detect clonal BM plasma cells in the majority of patients with EMP [26]. Furthermore, EMPs are very similar to MM both phenotypically and genetically, with the exception that EMPs are usually negative for the $\mathrm{t}(11 ; 14)$ translocation and markers of advanced disease, such as MYC translocations or TP53 alterations $[27,28]$. Despite this close relationship to MM, EMPs shows a good prognosis with local radiotherapy alone, and only about $15 \%$ of patients progress to systemic disease. This underlines the importance of non-genetic factors for disease progression. From the practical point of view, separation of generally indolent EMPs from aggressive extramedullary disease is of great importance, and usually relies on the clinical circumstances and certain pathological features such as cellular maturity and the identification of markers of aggressive disease (Figure 2).

MM focal lesions (FLs) are localized tumor cell accumulations that are present in the majority of MM patients at diagnosis and are detectable by advanced imaging modalities (Figure 3). FLs represent mutational hotspots consistent with the regional outgrowth of advanced tumor clones [29]. Detailed histopathological analyses on the cellular composition and spatial organization of MM FLs are largely lacking, mainly because of their frequently difficult localization and accessibility for radiological guided biopsy. Tissue from FLs can be obtained during surgery for pathological fractures, and preliminary studies on these FLs compared to matched random BM biopsies did not show significant differences in the proliferation rate of malignant plasma cells (L.R. and N.W., unpublished observations). However, systematic studies addressing the FLs' tissue characteristics, including mapping their 
Schürch et al.

immune tumor microenvironment, have not yet been performed, and there are surprisingly limited data on osteolytic lesions.

In summary, MM shows significant heterogeneity at the pathological level, and the pathologist can use morphological cues and IHC to guide downstream analyses, such as genetic testing. Future pathology studies in MM should focus on, and describe in detail, the spatial organization of FLs.

\section{Heterogeneity at the molecular genetic level}

MM is characterized by extensive inter-patient heterogeneity [30]. Yet, it can be broadly categorized into two groups: those with Ig heavy chain gene translocations involving chromosome 14q32 (including, in descending order of frequency, $\mathrm{t}(11 ; 14), \mathrm{t}(4 ; 14), \mathrm{t}(14 ; 16)$, $\mathrm{t}(14 ; 20)$ and $\mathrm{t}(6 ; 14))$; and those with hyperdiploid genomes (i.e., trisomies of odd-numbered chromosomes with the exception of 1,13 and 21). Additional gross chromosomal aberrations, such as deletions and amplifications, are often observed, leading to emergence of new subclones and intratumoral heterogeneity. To better understand intratumoral heterogeneity, we recently sequenced several $\mathrm{MM}$ samples from the same patient, including iliac crest and radiology-guided FL biopsies. Spatial genomic heterogeneity at the chromosomal and mutational level, where somatic aberrations were present at one site but absent at another (private mutations), was observed in the majority of patients. On average, three unshared copy number aberrations (CNAs) between paired samples were found in these patients. These

included spatial differences in commonly used prognostic markers such as $\operatorname{del}(17 \mathrm{p}), M Y C$ translocations, and aberrations of chromosome 1 . In contrast, initiating events such as $t(11 ; 14)$ and $t(4 ; 14)$ were uniformly shared among investigated regions, consistent with their role as early disease drivers. In addition, mutational analysis revealed that private mutations were found in $76 \%$ of newly diagnosed MM (NDMM) patients [29]. The non-homogeneous distribution of high-risk clones and potentially targetable driver mutations pose a significant 
Schürch et al.

challenge for correct risk classification and effective therapy [29, 31, 32]. The prime, clinically relevant example of spatial heterogeneity discovered in this study was in a patient who had an ultra-high-risk clone in a biopsy from the lumbar spine that had a high-risk score according to gene expression profiling (GEP) data, a bi-allelic TP53 deletion and an aberration of chromosome 1p, all of which were absent in the iliac crest biopsy. In contrast, the iliac crest biopsy was GEP low-risk, had a hyperdiploid karyotype and a $B R A F^{\mathrm{V} 600 \mathrm{E}}$ mutation.

A recent investigation of 1273 NDMM patients yielded profound insight into the interplay of commonly mutated genes. Walker et al. found significant associations between certain translocations, oncogene or tumor suppressor gene mutations, chromosomal copy number changes, and hyperdiploidy. Examples of such events included $t(11 ; 14)$ in combination with mutations in CCNDI and IRF4; $\mathrm{t}(4 ; 14)$ in combination with mutations in FGFR, DIS3 and PRKD2; and hyperdiploidy in combination with gain 11q, mutations in FAM46C and MYC rearrangements, amongst others [33]. Some of these mutations, such as those in CCND1 and $F G F R$, are probably the effect of aberrant somatic hypermutation targeting translocated genes. Furthermore, the authors observed a significant inverse correlation between the number of oncogenic driver mutations per sample and progression free as well as overall survival. In addition, this study found novel potentially targetable mutations in the epigenetic regulators $I D H 1$ and $I D H 2$, and identified associations between certain $B R A F$ mutations and chromosomal translocations, i.e. $\mathrm{t}(14 ; 16)$ and $B R A F^{\mathrm{D} 594 \mathrm{~N}}$, and $\mathrm{t}(4 ; 14)$ and $B R A F^{\mathrm{V} 600 \mathrm{E}}$ [33]. The latter finding is clinically relevant since BRAF inhibitors are selective for BRAF ${ }^{\mathrm{V} 600 \mathrm{E}}$ and should not be used in patients with BRAF ${ }^{\mathrm{D} 54 \mathrm{~N}}$ or $\mathrm{RAS}$ mutations $[31,34,35]$.

\section{Heterogeneity at the radiological level}

MM intra- and intertumoral heterogeneity are clearly reflected at the radiological level. While some patients present with a diffuse plasma cell BM infiltration only, up to $75 \%$ of patients show FLs, localized accumulations of tumor cells in the skeletal system (Figure 3). Number, 
Schürch et al.

size, location in the skeleton (axial vs. appendicular), type (intra-, para- or extramedullary), and metabolism of FLs differ between patients, dramatically increasing the extent of inter-patient heterogeneity in MM. The two main imaging techniques used for disease detection are ${ }^{18} \mathrm{~F}$ fluorodeoxyglucose positron emission tomography/computed tomography (FDG-PET/CT) and diffusion weighted magnetic resonance imaging (DW-MRI). While FDG-PET/CT is based on the quantification of increased glucose uptake by tumor cells, in DW-MRI cellularity is measured by quantifying the diffusion of water molecules and the microcirculation of blood in the capillary network [36, 37]. FDG-PET/CT and DW-MRI have comparable diagnostic accuracy, and DW-MRI has the advantage of not exposing the patient to ionizing radiation [3840].

Clinically, the focus has been on the number and type of FLs. Both, EMD and more than 3 FLs in FDG-PET/CT negatively impact outcome [41-46]. Another variable that seems to impact prognosis is the location of FLs: Abe et al. recently showed that MM patients with multiple FLs in the appendicular skeleton suffered from poor outcome [47]. Combining wholebody functional imaging and data from multi-region sequencing, we identified the size of FLs as an important variable $[29,46]$. We demonstrated that spatial differences were mainly seen in patients with large $(>2.5 \mathrm{~cm}) \mathrm{FLs}$, suggesting that clinical imaging can be used to identify patients with extensive intratumoral heterogeneity. Indeed, using the size of FLs as a surrogate marker for the level of intratumoral heterogeneity, we showed that the presence of multiple large FLs was an independent adverse prognostic factor in MM [46]. Accounting for the size of FLs, more than 3 FLs in FDG-PET/CT were not prognostically relevant anymore.

We have shown that highly advanced clones can be restricted to an FL [29]. Since response to treatment could be different at that location compared to other sites in the BM, the question becomes whether iliac crest sampling is sufficient for disease monitoring during treatment. We and others have recently tested the value of imaging as an alternative method for detection of minimal residual disease (MRD) $[25,48]$. Using the two functional methods, DW-MRI and 
Schürch et al.

FDG-PET/CT, we showed that one fourth of NDMM patients still had residual FLs when they achieved complete remission (CR). Combining flow cytometry for MRD detection and the two imaging methods, we demonstrated that less than $10 \%$ of MRD-negative NDMM patients in CR still presented with residual FLs. In contrast, $\sim 50 \%$ of heavily pretreated patients who achieved MRD-negative CR during salvage therapy presented with FLs, illustrating the value of functional imaging in these patients [49]. Last but not least, the spleen signal on DW-MRI also provides prognostic information, in that patients lacking spleen signal usually show high tumor burden and poor prognosis, especially when suffering from high-risk disease [50].

\section{Role of the BM microenvironment and host immunity in MM heterogeneity}

Recent evidence indicates that intratumoral heterogeneity can be influenced by clonal competition, clonal cooperativity, $\mathrm{pH}$, oxygenation, and the $\mathrm{BM}$ microenvironment (BMME) $[4-6,9,51,52]$. The role of the BMME in MM pathogenesis has been extensively reviewed [53-57]. The BM is a complex organ consisting of numerous highly specialized cell lineages that orchestrate blood production, immunity, and skeletal integrity over a lifetime of an organism. Because mature, long-lived plasma cells primarily reside in the BM, the BMME is key in the development and progression of MM (Figure 4) [54]. As an immunological organ by itself, the BM hosts a wide range of immature and mature innate and adaptive immune cell types [58]. To accommodate its high metabolic needs, the BM is also richly vascularized with different types of arterioles, transitional capillaries, and sinusoids [59]. Besides these cellular compartments, which also include mesenchymal cells such as BM stromal cells, adipocytes and osteolineage cells, the BMME consists of solid extracellular matrix components (such as collagenous bone) and a liquid milieu containing growth factors, cytokines and chemokines. Immune, stromal, osseous and endothelial cells all contribute to this milieu, which promotes survival, proliferation, and drug resistance of MM cells [56]. By secreting regulatory cytokines such as transforming growth factor (TGF)- $\beta$ and interleukin (IL)-10, MM cells induce a local 
Schürch et al.

and systemic immunosuppression that prevents host antitumoral immunity and contributes to an increased susceptibility to infections [60]. In addition, MM cells produce angiogenic factors such as vascular endothelial growth factor (VEGF), angiopoietin-1 and fibroblast growth factor (FGF), which contribute to the enhanced BM angiogenesis observed in MM patients [55, 61]. Interestingly, MM cells also produce exosomes that carry multiple angiogenic factors and directly promote endothelial cell growth [62]. Of note, Nakamura et al. recently demonstrated that IL-18, produced by multiple cell types in the BMME, drove the generation of MMsupporting myeloid-derived suppressor cells (MDSCs) that negatively impacted antitumoral $\mathrm{CD}^{+} \mathrm{T}$ cell responses, and showed that high IL-18 levels in BM plasma were associated with poor outcome in MM patients [63]. Indeed, BM MDSCs were already reported earlier to play a pivotal role in MM pathogenesis [64]. In addition to cytokines and growth factors, MM cells express adhesion factors such as CD38 that allow them to adhere to BM endothelial and stromal cells. BM stromal cells in turn up-regulate the expression of IL-6 and other cytokines that activate osteoclasts (OCs) and drive MM cell proliferation [53]. Interestingly, a study by Frenquelli et al. showed that ROR2, a receptor for the non-canonical WNT pathway, is essential for MM cell interactions with the BMME, and that ROR2 inhibition led to MM cell detachment resulting in apoptosis [65]. OCs, bone resorbing cells that are formed as giant syncytia by the fusion of monocytes, are mainly responsible for the MM-specific bone lesions and the increased risk of fractures. OC numbers and activity are strongly enhanced in MM, and OCs directly protect $\mathrm{MM}$ cells from immune action by $\mathrm{CD} 4^{+}$and $\mathrm{CD} 8^{+} \mathrm{T}$ cells [66]. Numerous additional BMME cell types including osteoblasts, macrophages and plasmacytoid dendritic cells were shown to contribute to MM pathogenesis [67-69]. Many currently available MM therapies, including immunomodulators and bisphosphonates, exert their functions at least in part by affecting non-tumor cells in the BMME [56]. However, insights into the mechanisms by which the BMME supports or even promotes MM heterogeneity are almost completely lacking. An important factor for the establishment of intratumoral heterogeneity is the ability of MM cells 
Schürch et al.

to mobilize into the bloodstream and re-enter the BM at different sites. The chemokine receptor CXCR4, a key mediator of hematopoietic stem cell retention in the BM, also plays a role in the interactions of MM cells with the BMME. Inhibiting CXCR4 with the drug plerixafor (AMD3100) disrupted these interactions, mobilized MM cells into the periphery and increased their sensitivity to multiple therapeutic agents [70].

In summary, the BMME and host immunity both are crucial factors in $\mathrm{MM}$ pathogenesis. Future studies should address how they contribute to MM genetic heterogeneity and why end-stage diseases such as EMD and PCL lose their dependence on microenvironmental survival signals. Answering these important questions will improve our understanding of MM in general and pave the way for future therapies.

\section{Current therapy and the impact of tumor heterogeneity}

Although molecular segmentation strategies have shown the extent of tumor heterogeneity in MM, the standard clinical approach is still more akin to "one size fits all". Younger individuals and medically fit patients aged up to 75 years undergo induction therapy utilizing at least one of the so-called novel agents lenalidomide or bortezomib, followed by peripheral stem cell apheresis, high-dose melphalan therapy, auto-transplant, and lenalidomide maintenance therapy. In some centers, a second high-dose therapy with auto-transplant 2-6 months after the first transplant ("tandem") is preferred over a single transplant. The standard dose of melphalan is $200 \mathrm{mg} / \mathrm{m}^{2}$; in elderly or frail patients the dose is frequently reduced to $140 \mathrm{mg} / \mathrm{m}^{2}$. Consolidation therapy after auto-transplant is another strategy to improve depth of response, and probably outcomes. The efficacy of these additional elements is still a matter of debate [71]. However, Total Therapies, which include multi-agent induction therapy, two autotransplants, consolidation, and intensified maintenance have produced the best reported outcomes so far with some patients even considered to be cured [72]. Treatment for transplant- 
Schürch et al.

ineligible patients typically consists of doublet or triplet drug regimens, which are frequently combined with daratumumab, an anti-CD38 monoclonal antibody [73, 74].

Only few studies have investigated specific treatments for GEP-defined high- and lowrisk disease $[75,76]$. Unfortunately, these studies were not successful and could neither support intensification in high-risk nor de-escalation in low-risk patients. In a study by Cavo et al., patients with high-risk disease, defined there as international staging system (ISS, Table 2) stage II+III, high-risk cytogenetics and failure to achieve CR, benefited from tandem transplant as compared to single transplant (median progression-free survival: 35 vs. 14 months). However, overall survival in the high-risk group was still clearly inferior when compared to standard-risk patients. These results suggest that double-transplant delays disease progression in high-risk patients but does not overcome high-risk disease per se [77]. In summary, current clinical practice usually does not take into account tumor heterogeneity, with a few exceptions, which are discussed below, and recapitulated in Table 3.

Treatment with venetoclax, an oral $\mathrm{BH} 3$-mimetic, in patients harboring translocation $\mathrm{t}(11 ; 14)$ is a good first example for individualized $\mathrm{MM}$ therapy utilizing the distinct susceptibility of this molecular subtype to BCL-2 inhibition. Tumor cells with $t(11 ; 14)$ show a more B cell-like phenotype and more likely express high levels of BCL-2 relative to BCL- $\mathrm{X}_{\mathrm{L}}$ and MCL-1. Evaluating single-agent venetoclax in R/R MM, the overall response rate was 21\%, and most responses $(86 \%)$ were seen in patients with $\mathrm{t}(11 ; 14)$ translocation, with $27 \%$ of these patients achieving a very good partial response (VGPR) or better [78]. Combining venetoclax with bortezomib and dexamethasone the overall response rate was $67 \%$ in patients with $\mathrm{R} / \mathrm{R}$ MM, and $42 \%$ of patients achieved a VGPR or better [79]. Response was not limited to cases with $\mathrm{t}(11 ; 14)$, but best overall response rate was observed in patients with high BCL-2 expression (94\%). Notably, patients with bortezomib-sensitive disease were more likely to respond than those whose disease was refractory to prior bortezomib, suggesting that 
Schürch et al.

venetoclax cannot fully overcome bortezomib resistance [80]. In summary, treatment with venetoclax in patients with $\mathrm{t}(11 ; 14)$ represents the prime example for personalized MM therapy. However, venetoclax is not yet officially approved for the treatment of MM by the United States Food and Drug Administration (FDA), and it is not mentioned in the National Comprehensive Cancer Network (NCCN) guidelines for MM [81].

Another good example is the impact of proteasome inhibitors on t(4;14)-positive MM, a subgroup with dismal outcomes before the introduction of this class of drugs. At the University of Arkansas for Medical Sciences in Little Rock, Dr. Barlogie and team treated patients with several generations of Total Therapy encompassing multi-agent induction therapy, two auto-transplants, and intensified maintenance. Bortezomib was introduced in Total Therapy $3 a$ in the induction, consolidation and maintenance phase of therapy. A survival benefit was mainly seen for patients with $\mathrm{t}(4 ; 14)$, highlighting a favorable effect of proteasome inhibition particularly in this subgroup [12]. Avet-Loiseau et al. reported on 507 NDMM patients treated with bortezomib/dexamethasone induction followed by transplant and also observed significantly improved overall survival for $\mathrm{t}(4 ; 14)$ positive cases [82]. In summary, proteasome inhibitors improve outcomes in patients with $\mathrm{t}(4 ; 14)$. Bortezomib maintenance is one option recommended in the NCCN guidelines for MM [81].

The third example for personalized therapy is the use of vemurafenib and other BRAF and MEK inhibitors in $B R A F^{\mathrm{V} 600 \mathrm{E}}$ mutated $\mathrm{MM}$ [83-85]. Mutations at this location occur in $>5 \%$ of NDMM and the frequency increases from baseline to relapse $[83,86]$. Raab et al. and others have reported on patients achieving $\mathrm{CR}$ after BRAF targeted therapy in $\mathrm{R} / \mathrm{R} \mathrm{MM}$, and a phase 2 trial (BIRMA trial, NCT02834364) is currently evaluating this concept in a larger number of patients [83]. However, although being the proof of concept for targeting actionable mutations, duration of response is often short and patients relapse with $B R A F^{\mathrm{V} 600 \mathrm{E}}$ negative clones [31]. Moreover, mutations in genes involved in the MAP kinase pathway are subclonal in the majority of patients $[31,87]$ and spatial genomic heterogeneity has been reported for 
Schürch et al.

these potential targets [29]. Together, targeting mutations in MM may be an approach for $\mathrm{R} / \mathrm{R}$ patients with limited therapeutic options. However, we recommend genomically characterizing these patients and discussing the results in the framework of a molecular tumor board.

\section{Conclusions}

Recent research has uncovered a striking amount of inter- and intratumoral heterogeneity in PCNs at all levels of investigation. Despite our increased understanding of PCNs and better therapies, which have resulted in an improved outlook for the majority of patients, spatially distributed genetic and biological heterogeneity with outgrowth of aggressive and therapy-resistant subclones still preclude long-term cure in most patients. The combination of advanced imaging modalities combined with targeted genetic investigation of FLs may lead to better risk estimation and early identification and targeting of aggressive subclones. Yet, how the ever more complex personalized $\mathrm{MM}$ medicine can be harmonized with increasing economic pressures and patient dignity is a challenge for the future. 
Schürch et al.

\section{Tables}

Table 1: WHO definition of MM

\begin{tabular}{|c|c|}
\hline Parameter & Diagnostic criterion \\
\hline \multicolumn{2}{|c|}{ 1. Clonal plasma cell neoplasm (clonality proven by IHC, IF or flow cytometry) } \\
\hline Clonal BM plasma cells & $>10 \%$ \\
\hline \multicolumn{2}{|r|}{ OR } \\
\hline Plasmacytoma & biopsy-proven \\
\hline \multicolumn{2}{|r|}{ AND } \\
\hline \multicolumn{2}{|c|}{ 2. Any one of the following myeloma-defining events } \\
\hline $\begin{array}{l}\text { Any one of the } \\
\text { following criteria of } \\
\text { end-organ damage } \\
\text { (CRAB-criteria) }\end{array}$ & $\begin{array}{l}\text { HyperCalcemia }(>0.25 \mathrm{mmol} / \mathrm{L} \text { above normal or }>2.75 \\
\mathrm{mmol} / \mathrm{L}) \\
\text { Renal insufficiency (creatinine clearance }<40 \mathrm{ml} / \mathrm{min} \text { or serum } \\
\text { creatinine }>177 \mu \mathrm{mol} / \mathrm{L} \\
\text { Anemia (hemoglobin }>20 \mathrm{~g} / \mathrm{L} \text { below normal, or }<100 \mathrm{~g} / \mathrm{L} \text { ) } \\
\text { Bone lesions (one or more osteolytic lesions on skeletal } \\
\text { radiography, CT, or }{ }^{18} \mathrm{~F}-\mathrm{FDG}-\mathrm{PET} / \mathrm{CT}\end{array}$ \\
\hline & OR \\
\hline $\begin{array}{l}\text { Any one of the } \\
\text { following biomarkers of } \\
\text { malignancy }\end{array}$ & $\begin{array}{l}\text { - Clonal BM plasma cells } \geq 60 \% \\
\text { - Involved-to-uninvolved serum free light chain ratio } \geq 100 \\
\text { (involved free light chain must be } \geq 100 \mathrm{mg} / \mathrm{L} \text { ) } \\
\text { - }>1 \text { focal lesion on } \mathrm{MRI} \text { (each } \geq 5 \mathrm{~mm} \text { in size) }\end{array}$ \\
\hline
\end{tabular}

Adapted from [13, 88]

Table 2: International Staging System (ISS) and Revised ISS (R-ISS) for MM

\begin{tabular}{|c|c|c|}
\hline Parameter & ISS stage I & R-ISS stage I \\
\hline & all of the following: & all of the following: \\
\hline Serum albumin & $\geq 35 \mathrm{~g} / \mathrm{L}$ & $\geq 35 \mathrm{~g} / \mathrm{L}$ \\
\hline Serum $\beta_{2}$-microglobulin & $<3.5 \mathrm{mg} / \mathrm{L}$ & $<3.5 \mathrm{mg} / \mathrm{L}$ \\
\hline Serum lactate dehydrogenase & not considered & normal \\
\hline \multirow[t]{2}{*}{ Cytogenetics } & not considered & $\begin{array}{l}\text { non-high-risk: absence of } \\
\mathrm{t}(4 ; 14), \mathrm{t}(14 ; 16), \operatorname{del}(17 \mathrm{p})\end{array}$ \\
\hline & ISS stage II & R-ISS stage II \\
\hline \multirow[t]{2}{*}{ ISS / R-ISS stage } & not ISS stage I or III & not R-ISS stage I or III \\
\hline & ISS stage III & R-ISS stage III \\
\hline \multirow[t]{2}{*}{ Serum $\beta_{2}$-microglobulin } & $\geq 5.5 \mathrm{mg} / \mathrm{L}$ & $\geq 5.5 \mathrm{mg} / \mathrm{L}$ \\
\hline & & AND \\
\hline \multirow[t]{2}{*}{ Serum lactate dehydrogenase } & not considered & elevated \\
\hline & & OR \\
\hline Cytogenetics & not considered & $\begin{array}{l}\text { high-risk: presence of } \\
\mathrm{t}(4 ; 14), \mathrm{t}(14 ; 16) \text { or } \operatorname{del}(17 \mathrm{p})\end{array}$ \\
\hline
\end{tabular}

Adapted from $[2,89]$ 
Table 3: Molecular abnormalities, their effects, prognostic impact, and candidate drugs / therapeutic implications

\begin{tabular}{|c|c|c|c|c|}
\hline $\begin{array}{l}\text { Molecular } \\
\text { abnormality }\end{array}$ & Effect / function & $\begin{array}{l}\text { Prognostic } \\
\text { impact }\end{array}$ & $\begin{array}{l}\text { Candidate drugs / } \\
\text { therapeutic } \\
\text { implications }\end{array}$ & References \\
\hline $\begin{array}{l}\mathrm{t}(4 ; 14) \\
(10-15 \% \text { of } \\
\text { patients })\end{array}$ & $\begin{array}{l}\text { Overexpression of } \\
\text { MMSET and } \\
\text { FGFR3; increased } \\
\text { histone H3K } \\
\text { methylation, up- } \\
\text { regulation of } \\
\text { CCND2 }\end{array}$ & $\begin{array}{l}\text { Adverse } \\
\text { prognosis }\end{array}$ & $\begin{array}{l}\text { Bortezomib } \\
\text { (improves } \\
\text { survival) }\end{array}$ & {$[1,12,30,81]$} \\
\hline $\begin{array}{l}\mathrm{t}(6 ; 14) \\
(\sim 1 \% \text { of } \\
\text { patients })\end{array}$ & $\begin{array}{l}\text { Overexpression of } \\
\text { CCND3 leading } \\
\text { to malignant } \\
\text { trans-formation }\end{array}$ & Neutral & $\begin{array}{l}\text { Palbociclib } \\
\text { (CDK4/6 inhibitor) }\end{array}$ & $\begin{array}{l}{[1,12,30]} \\
\text { NCT03297606 } \\
\text { NCT02465060 } \\
\text { NCT02693535 } \\
\text { NCT00555906 } \\
\text { NCT02030483 } \\
\end{array}$ \\
\hline $\begin{array}{l}t(14 ; 16) \\
(3-5 \% \text { of } \\
\text { patients })\end{array}$ & $\begin{array}{l}\text { Overexpression of } \\
\text { MAF leading to } \\
\text { up-regulation of } \\
\text { CCND2, } \\
\text { "APOBEC } \\
\text { signature" } \\
\text { (increased } \\
\text { mutation rate) }\end{array}$ & $\begin{array}{l}\text { Adverse } \\
\text { prognosis } \\
\text { (neutral in a } \\
\text { large study } \\
\text { with } 1004 \\
\text { patients [90]) }\end{array}$ & - & $\begin{array}{l}{[1,12,30,90,} \\
91]\end{array}$ \\
\hline $\begin{array}{l}t(11 ; 14) \\
(15-20 \% \text { of } \\
\text { patients })\end{array}$ & $\begin{array}{l}\text { Overexpression of } \\
\text { CCND1 under } \\
\text { IgH promoter } \\
\text { leading to } \\
\text { malignant trans- } \\
\text { formation; } \\
\text { proliferation; } \\
\text { dependence on } \\
\text { anti-apoptotic } \\
\text { proteins }\end{array}$ & $\begin{array}{l}\begin{array}{l}\text { Neutral } \\
\text { (co-occurrence }\end{array} \\
\text { with activating } \\
\text { CCND1 } \\
\text { mutations in } \\
10 \% \text { associated } \\
\text { with adverse } \\
\text { prognosis }\end{array}$ & $\begin{array}{l}\text { BH3-mimetics } \\
\text { (e.g. venetoclax) } \\
\text { MCL1-inhibitors } \\
\text { (e.g. MIK665, } \\
\text { AMG397) } \\
\text { Palbociclib } \\
\text { (CDK4/6 inhibitor) }\end{array}$ & $\begin{array}{l}{[79,80]} \\
{[92]} \\
\text { NCT02992483 } \\
\text { NCT03465540 } \\
\text { NCT03297606 } \\
\text { NCT02465060 } \\
\text { NCT02693535 } \\
\text { NCT00555906 } \\
\text { NCT02030483 }\end{array}$ \\
\hline $\begin{array}{l}\mathrm{t}(14 ; 20) \\
(\sim 1 \% \text { of } \\
\text { patients })\end{array}$ & $\begin{array}{l}\text { Overexpression of } \\
\text { MAFB leading to } \\
\text { up-regulation of } \\
\text { CCND2, } \\
\text { "APOBEC } \\
\text { signature" } \\
\text { (increased } \\
\text { mutation rate) }\end{array}$ & $\begin{array}{l}\text { Adverse } \\
\text { prognosis }\end{array}$ & - & {$[1,12,30,91]$} \\
\hline $\begin{array}{l}\text { ADAR1 over- } \\
\text { expression } \\
\text { (due to 1q21 } \\
\text { amplification } \\
\text { present in up }\end{array}$ & $\begin{array}{l}\text { Transcriptome } \\
\text { hyper-editing }\end{array}$ & $\begin{array}{l}\text { Disease } \\
\text { progression } \\
\text { and } \\
\text { aggressiveness }\end{array}$ & $\begin{array}{l}\text { 8-Azaadenosine } \\
\text { (could be a } \\
\text { candidate drug to } \\
\text { inhibit ADAR1) }\end{array}$ & [93] \\
\hline
\end{tabular}


Schürch et al.

\begin{tabular}{|c|c|c|c|c|}
\hline $\begin{array}{l}\text { to } 45 \% \text { of } \\
\text { patients) }\end{array}$ & & & $\begin{array}{l}\text { Resistance to PD-1 } \\
\text { immune check- } \\
\text { point blockade }\end{array}$ & [94] \\
\hline $\begin{array}{l}\text { Mutations in } \\
\text { BRAF (6- } \\
12 \% \text { of } \\
\text { patients), } \\
\text { KRAS ( } 20 \% \\
\text { of patients), } \\
\text { NRAS ( } 20 \% \\
\text { of patients) }\end{array}$ & $\begin{array}{l}\text { MAPK pathway } \\
\text { activation }\end{array}$ & $\begin{array}{l}\text { Associated } \\
\text { with disease } \\
\text { progression } \\
\text { (mutations } \\
\text { often } \\
\text { subclonal) }\end{array}$ & $\begin{array}{l}\text { Encorafenib } \\
\text { Binimetinib } \\
\text { Trametinib } \\
\text { Selumetinib } \\
\text { Vemurafenib }\end{array}$ & $\begin{array}{l}{[31,83-86]} \\
\text { NCT02834364 } \\
\text { NCT01989598 } \\
\text { NCT01085214 } \\
\text { NCT01524978 }\end{array}$ \\
\hline $\begin{array}{l}\text { MAF over- } \\
\text { expression } \\
\text { (30\% of } \\
\text { patients) }\end{array}$ & $\begin{array}{l}\text { Alteration of } \\
\text { integrin beta } 7 \text {, } \\
\text { up-regulation of } \\
\text { CCR 1 }\end{array}$ & $\begin{array}{l}\text { Increased BM } \\
\text { homing and } \\
\text { survival in the } \\
\text { BMME }\end{array}$ & - & {$[30]$} \\
\hline $\begin{array}{l}\text { MYC over- } \\
\text { expression } \\
\text { (secondary } \\
\text { translocations, } \\
\text { in } 15-20 \% \text { of } \\
\text { patients) }\end{array}$ & $\begin{array}{l}\text { Kataegis } \\
\text { (localized } \\
\text { hypermutation } \\
\text { pattern linked to } \\
\text { APOBEC } \\
\text { deregulation) }\end{array}$ & $\begin{array}{l}\text { Adverse } \\
\text { prognosis }\end{array}$ & $\begin{array}{l}\text { CPI-0610 } \\
\text { (BET inhibitor) }\end{array}$ & NCT02157636 \\
\hline $\begin{array}{l}\text { SK2 over- } \\
\text { expression } \\
\text { (not } \\
\text { correlated } \\
\text { with } \\
\text { cytogenetic } \\
\text { abnormalities) }\end{array}$ & Production of S1P & $\begin{array}{l}\text { Mitogenic and } \\
\text { anti-apoptotic } \\
\text { functions of } \\
\text { S1P }\end{array}$ & $\mathrm{ABC} 294640$ & $\begin{array}{l}{[95]} \\
\text { NCT02757326 }\end{array}$ \\
\hline
\end{tabular}

Adapted in part from [1]. Abbreviations: ADAR1, adenosine deaminase acting on RNA 1; APOBEC, apolipoprotein B mRNA editing enzyme, catalytic polypeptide-like; BET, bromodomain and extra-terminal motif protein; BH3, BCL-2 homology domain 3; BM, bone marrow; BMME, BM microenvironment; CCND, Cyclin D; CDK, cyclin-dependent kinase; CCR1 C-C chemokine receptor 1; FGFR3, fibroblast growth factor receptor 3; MAF, V-Maf Avian Musculoaponeurotic Fibrosarcoma Oncogene Homolog; MAP, mitogen-activated protein kinase; MCL-1, myeloid cell leukemia-1; MMSET, multiple myeloma SET domain; MYC, V-Myc Avian Myelocytomatosis Viral Oncogene Homolog; PD-1, programmed cell death protein-1; S1P, sphingosine-1-phosphate; SK2, sphingosine kinase 2 
Schürch et al.

\section{Figure legends}

Figure 1. Tumor heterogeneity in MM. At the highest genomic level, interpatient/intertumoral heterogeneity (top panel) can be viewed as patients having tumors with hyperdiploid genomes $(\sim 50 \%)$ or primary $\operatorname{Ig}$ heavy chain $(\operatorname{IgH})$ translocations $(\sim 50 \%)$, with rare exceptions showing a combination of both. Moreover, there is a vast variability at the level of additional driver mutations between patients, as well as differences in the distribution of lesions and their histomorphological appearance, further contributing to intertumoral heterogeneity (not depicted). Intra-patient/intratumoral heterogeneity (bottom panel) can be described as the heterogeneous distribution of genetically distinct MM clones and subclones within a single patient. Intratumoral heterogeneity may complicate diagnostics and classification and represents a significant challenge for optimal personalized therapy.

Figure 2. Heterogeneity at the pathological level. (A-E) Extramedullary solitary plasmacytoma of the upper airways shows an infiltration by mature plasma cells with absence of significant atypia. (A-B) Giemsa staining, 100x and 400x magnification, respectively. (C-E) IHC for (C) MUM-1/IRF-4, (D) kappa (highlighting the malignant clone), and (E) lambda light chains (highlighting rare reactive plasma cells). Magnification, 400x. (F-I) Osteolytic lesion of anaplastic MM with large, immunoblast-like cells with narrow rims of basophilic cytoplasm and large central nucleoli, numerous atypical mitoses, and apoptotic bodies. (F) Hematoxylin \& eosin (H\&E) staining, (G) Giemsa staining. Magnification, 400x. (H-I) IHC for (H) MYC (only rare positive cells), and (I) Ki-67/MIB-1 (>80\% positive cells). Magnification, 100x. (JK) Medullary anaplastic MM a predominant population of small to medium sized cells and scattered cells with anaplastic morphology. (J) H\&E staining, (K) IHC for p53 (homogenous and strong positive staining, indicative of p53-mutation). Magnification, 200x. (L-N) MM with lymphoplasmacytoid morphology of the BM. (L) H\&E staining, (M) Giemsa staining. 
Schürch et al.

Magnification, 200x. (N) IHC for cyclin D1 (marked overexpression, indicative of a chromosome 11 translocation). Magnification, 400x.

Figure 3. Heterogeneity at the radiological level. Up to $75 \%$ of myeloma patients present with FLs, and a high number and large size of FLs both are associated with an adverse prognosis. FDG-PET (left image) and DW-MRI (right image) of the same patient show heterogeneous disease involvement with multiple FLs. Some FLs are well visible in both imaging modalities (blue circles), whereas other FLs are much more pronounced in the DWMRI (red circles). A possible explanation for these differences is metabolic heterogeneity, in that some FLs may express lower levels of hexokinase-2, impairing their uptake of glucose $[36]$.

Figure 4. Role of BM microenvironment and host immunity in MM pathogenesis. MM cells produce immunosuppressive cytokines including IL-10 and TGF- $\beta$ (center), directly inhibiting $\mathrm{T}$ cell responses. In addition, MM cells secrete angiogenic factors VEGF, FGF and ANGPT1 that contribute to BM angiogenesis (bottom left). Multiple cell types of the BMME produce IL-18, which supports the generation of MDSCs that inhibit $\mathrm{CD}^{+} \mathrm{T}$ cell responses (top left). The CXCL12-CXCR4 interaction is important for MM cell retention in the BMME. Furthermore, adhesion of MM cells to BMSCs, mediated in part by CD38, activates BMSCs to produce IL-6, which in turn stimulates OCs for increased bone resorption (bottom center). OCs also directly inhibit the proliferation of $\mathrm{CD}^{+}$and $\mathrm{CD} 8^{+} \mathrm{T}$ cells (top right). Blue arrows indicate stimulation, red arrows indicate inhibition. Abbreviations: ANGPT1, angiopoietin-1; BMME, bone marrow microenvironment; BMSCs, bone marrow stromal cells; CXCL12, C-X-C chemokine ligand type 12; CXCR4, C-X-C chemokine receptor type 4; FGF, fibroblast growth factor; IL, interleukin; MDSCs, myeloid-derived suppressor cells; MM cell, multiple myeloma 
Schürch et al.

cell; OBs, osteoblasts; OCs, osteoclasts; TGF- $\beta$, transforming growth factor- $\beta$; VEGF, vascular endothelial growth factor. Parts of this figure were created with BioRender.com. 
Schürch et al.

\section{Compliance with ethical standards}

The authors state that they comply with the ethical standards specified by Virchows Archiv.

\section{Acknowledgments / Funding}

C.M.S. was supported by an Advanced Postdoc Mobility Fellowship from the Swiss National Science Foundation (P300PB_171189 and P400PM_183915). L.R. was supported by the German Cancer Aid (Krebshilfe) via the MSNZ program.

\section{Conflicts of interest}

The authors declare that no conflicts of interest exist.

\section{Author contributions}

All authors contributed to the writing and revision of the manuscript and accepted its final version. 
Schürch et al.

\section{References}

1. Manier S, Salem KZ, Park J, Landau DA, Getz G, Ghobrial IM (2017) Genomic complexity of multiple myeloma and its clinical implications Nat Rev Clin Oncol 14:100-113. doi: 10.1038/nrclinonc.2016.122

2. Palumbo A, Avet-Loiseau H, Oliva S, Lokhorst HM, Goldschmidt H, Rosinol L, Richardson P, Caltagirone S, Lahuerta JJ, Facon T, Bringhen S, Gay F, Attal M, Passera R, Spencer A, Offidani M, Kumar S, Musto P, Lonial S, Petrucci MT, Orlowski RZ, Zamagni E, Morgan G, Dimopoulos MA, Durie BG, Anderson KC, Sonneveld P, San Miguel J, Cavo M, Rajkumar SV, Moreau P (2015) Revised International Staging System for Multiple Myeloma: A Report From International Myeloma Working Group J Clin Oncol 33:2863-2869. doi:

10.1200/JCO.2015.61.2267

3. Bianchi G, Munshi NC (2015) Pathogenesis beyond the cancer clone(s) in multiple myeloma Blood 125:3049-3058. doi: 10.1182/blood-2014-11-568881

4. Swanton C (2012) Intratumor heterogeneity: evolution through space and time Cancer Res 72:4875-4882. doi: 10.1158/0008-5472.CAN-12-2217

5. Ding L, Wendl MC, McMichael JF, Raphael BJ (2014) Expanding the computational toolbox for mining cancer genomes Nat Rev Genet 15:556-570. doi: 10.1038/nrg3767

6. McGranahan N, Swanton C (2015) Biological and therapeutic impact of intratumor heterogeneity in cancer evolution Cancer cell 27:15-26. doi:

10.1016/j.ccell.2014.12.001

7. Marusyk A, Polyak K (2010) Tumor heterogeneity: causes and consequences Biochimica et biophysica acta 1805:105-117. doi: 10.1016/j.bbcan.2009.11.002

8. Visvader JE (2011) Cells of origin in cancer Nature 469:314-322. doi: 10.1038 /nature09781

9. Greaves M, Maley CC (2012) Clonal evolution in cancer Nature 481:306-313. doi: 10.1038 /nature 10762

10. Pawlyn C, Morgan GJ (2017) Evolutionary biology of high-risk multiple myeloma Nat Rev Cancer 17:543-556. doi: 10.1038/nrc.2017.63

11. Watanabe R, Tokuhira M, Kizaki M (2013) Current approaches for the treatment of multiple myeloma Int J Hematol 97:333-344. doi: 10.1007/s12185-013-1294-z

12. Weinhold N, Heuck CJ, Rosenthal A, Thanendrarajan S, Stein CK, Van Rhee F, Zangari M, Hoering A, Tian E, Davies FE, Barlogie B, Morgan GJ (2016) Clinical value of molecular subtyping multiple myeloma using gene expression profiling Leukemia 30:423-430. doi: 10.1038/leu.2015.309

13. Swerdllow SH, Campo E, Harris NL, Jaffe ES, Pileri SA, Stein H, Thiele J, Arber DA, Hasserjian RP, Le Beau MM, Orazi A, Siebert R (eds) (2017) WHO Classification of Tumours of Haematopoietic and Lymphoid Tissues. IARC Press, Lyon, Pages 
Schürch et al.

14. Fonseca R, Blood EA, Oken MM, Kyle RA, Dewald GW, Bailey RJ, Van Wier SA, Henderson KJ, Hoyer JD, Harrington D, Kay NE, Van Ness B, Greipp PR (2002) Myeloma and the $\mathrm{t}(11 ; 14)(\mathrm{q} 13 ; \mathrm{q} 32)$; evidence for a biologically defined unique subset of patients Blood 99:3735-3741

15. Specht K, Haralambieva E, Bink K, Kremer M, Mandl-Weber S, Koch I, Tomer R, Hofler H, Schuuring E, Kluin PM, Fend F, Quintanilla-Martinez L (2004) Different mechanisms of cyclin D1 overexpression in multiple myeloma revealed by fluorescence in situ hybridization and quantitative analysis of mRNA levels Blood 104:1120-1126. doi: 10.1182/blood-2003-11-3837

16. Reed M, McKenna RW, Bridges R, Parkin J, Frizzera G, Brunning RD (1981) Morphologic manifestations of monoclonal gammopathies Am J Clin Pathol 76:8-23

17. Feyler S, O'Connor SJ, Rawstron AC, Subash C, Ross FM, Pratt G, Drayson MT, Ashcroft J, Cook G, Owen RG (2008) IgM myeloma: a rare entity characterized by a CD20-CD56-CD117- immunophenotype and the $\mathrm{t}(11 ; 14)$ Br J Haematol 140:547-551. doi: $10.1111 / \mathrm{j} .1365-2141.2007 .06969 . x$

18. Lorsbach RB, Hsi ED, Dogan A, Fend F (2011) Plasma cell myeloma and related neoplasms Am J Clin Pathol 136:168-182. doi: 10.1309/AJCPENJ68FFBRIYB

19. Greipp PR, Raymond NM, Kyle RA, O'Fallon WM (1985) Multiple myeloma: significance of plasmablastic subtype in morphological classification Blood 65:305310

20. Bartl R, Frisch B, Fateh-Moghadam A, Kettner G, Jaeger K, Sommerfeld W (1987) Histologic classification and staging of multiple myeloma. A retrospective and prospective study of 674 cases Am J Clin Pathol 87:342-355. doi:

10.1093/ajcp/87.3.342

21. Paiva B, Vidriales MB, Perez JJ, Mateo G, Montalban MA, Mateos MV, Blade J, Lahuerta JJ, Orfao A, San Miguel JF, group GEMcs, group Pcs (2009) Multiparameter flow cytometry quantification of bone marrow plasma cells at diagnosis provides more prognostic information than morphological assessment in myeloma patients Haematologica 94:1599-1602. doi: 10.3324/haematol.2009.009100

22. Perez-Persona E, Mateo G, Garcia-Sanz R, Mateos MV, de Las Heras N, de Coca AG, Hernandez JM, Galende J, Martin-Nunez G, Barez A, Alonso JM, Martin A, LopezBerges C, Orfao A, San Miguel JF, Vidriales MB (2010) Risk of progression in smouldering myeloma and monoclonal gammopathies of unknown significance: comparative analysis of the evolution of monoclonal component and multiparameter flow cytometry of bone marrow plasma cells Br J Haematol 148:110-114. doi: $10.1111 / \mathrm{j} .1365-2141.2009 .07929 . x$

23. Kumar S, Paiva B, Anderson KC, Durie B, Landgren O, Moreau P, Munshi N, Lonial S, Blade J, Mateos MV, Dimopoulos M, Kastritis E, Boccadoro M, Orlowski R, Goldschmidt H, Spencer A, Hou J, Chng WJ, Usmani SZ, Zamagni E, Shimizu K, Jagannath S, Johnsen HE, Terpos E, Reiman A, Kyle RA, Sonneveld P, Richardson PG, McCarthy P, Ludwig H, Chen W, Cavo M, Harousseau JL, Lentzsch S, Hillengass J, Palumbo A, Orfao A, Rajkumar SV, Miguel JS, Avet-Loiseau H (2016) International Myeloma Working Group consensus criteria for response and minimal 
Schürch et al.

residual disease assessment in multiple myeloma Lancet Oncol 17:e328-e346. doi: 10.1016/S1470-2045(16)30206-6

24. Flores-Montero J, de Tute R, Paiva B, Perez JJ, Bottcher S, Wind H, Sanoja L, Puig N, Lecrevisse Q, Vidriales MB, van Dongen JJ, Orfao A (2016) Immunophenotype of normal vs. myeloma plasma cells: Toward antibody panel specifications for MRD detection in multiple myeloma Cytometry B Clin Cytom 90:61-72. doi: 10.1002/cyto.b.21265

25. Rasche L, Alapat D, Kumar M, Gershner G, McDonald J, Wardell CP, Samant R, Van Hemert R, Epstein J, Williams AF, Thanendrarajan S, Schinke C, Bauer M, Ashby C, Tytarenko RG, van Rhee F, Walker BA, Zangari M, Barlogie B, Davies FE, Morgan GJ, Weinhold N (2019) Combination of flow cytometry and functional imaging for monitoring of residual disease in myeloma Leukemia 33:1713-1722. doi: $10.1038 / \mathrm{s} 41375-018-0329-0$

26. Boll M, Parkins E, O'Connor SJ, Rawstron AC, Owen RG (2010) Extramedullary plasmacytoma are characterized by a 'myeloma-like' immunophenotype and genotype and occult bone marrow involvement Br J Haematol 151:525-527. doi: 10.1111/j.1365-2141.2010.08386.x

27. Kremer M, Ott G, Nathrath M, Specht K, Stecker K, Alexiou C, Quintanilla-Martinez L, Fend F (2005) Primary extramedullary plasmacytoma and multiple myeloma: phenotypic differences revealed by immunohistochemical analysis J Pathol 205:92101. doi: $10.1002 /$ path. 1680

28. Bink K, Haralambieva E, Kremer M, Ott G, Beham-Schmid C, de Leval L, Peh SC, Laeng HR, Jutting U, Hutzler P, Quintanilla-Martinez L, Fend F (2008) Primary extramedullary plasmacytoma: similarities with and differences from multiple myeloma revealed by interphase cytogenetics Haematologica 93:623-626. doi: 10.3324/haematol.12005

29. Rasche L, Chavan SS, Stephens OW, Patel PH, Tytarenko R, Ashby C, Bauer M, Stein C, Deshpande S, Wardell C, Buzder T, Molnar G, Zangari M, van Rhee F, Thanendrarajan S, Schinke C, Epstein J, Davies FE, Walker BA, Meissner T, Barlogie B, Morgan GJ, Weinhold N (2017) Spatial genomic heterogeneity in multiple myeloma revealed by multi-region sequencing Nat Commun 8:268. doi: 10.1038/s41467-017-00296-y

30. Morgan GJ, Walker BA, Davies FE (2012) The genetic architecture of multiple myeloma Nat Rev Cancer 12:335-348. doi: 10.1038/nrc3257

31. Raab MS, Lehners N, Xu J, Ho AD, Schirmacher P, Goldschmidt H, Andrulis M (2016) Spatially divergent clonal evolution in multiple myeloma: overcoming resistance to BRAF inhibition Blood 127:2155-2157. doi: 10.1182/blood-2015-12686782

32. Kuiper R, van Duin M, van Vliet MH, Broijl A, van der Holt B, El Jarari L, van Beers EH, Mulligan G, Avet-Loiseau H, Gregory WM, Morgan G, Goldschmidt H, Lokhorst HM, Sonneveld P (2015) Prediction of high- and low-risk multiple myeloma based on gene expression and the International Staging System Blood 126:1996-2004. doi: 10.1182/blood-2015-05-644039 
Schürch et al.

33. Walker BA, Mavrommatis K, Wardell CP, Ashby TC, Bauer M, Davies FE, Rosenthal A, Wang H, Qu P, Hoering A, Samur M, Towfic F, Ortiz M, Flynt E, Yu Z, Yang Z, Rozelle D, Obenauer J, Trotter M, Auclair D, Keats J, Bolli N, Fulciniti M, Szalat R, Moreau P, Durie B, Stewart AK, Goldschmidt H, Raab MS, Einsele H, Sonneveld P, San Miguel J, Lonial S, Jackson GH, Anderson KC, Avet-Loiseau H, Munshi N, Thakurta A, Morgan GJ (2018) Identification of novel mutational drivers reveals oncogene dependencies in multiple myeloma Blood 132:587-597. doi: 10.1182/blood2018-03-840132

34. Heidorn SJ, Milagre C, Whittaker S, Nourry A, Niculescu-Duvas I, Dhomen N, Hussain J, Reis-Filho JS, Springer CJ, Pritchard C, Marais R (2010) Kinase-dead $\mathrm{BRAF}$ and oncogenic RAS cooperate to drive tumor progression through CRAF Cell 140:209-221. doi: 10.1016/j.cell.2009.12.040

35. Chapman PB, Hauschild A, Robert C, Haanen JB, Ascierto P, Larkin J, Dummer R, Garbe C, Testori A, Maio M, Hogg D, Lorigan P, Lebbe C, Jouary T, Schadendorf D, Ribas A, O'Day SJ, Sosman JA, Kirkwood JM, Eggermont AM, Dreno B, Nolop K, Li J, Nelson B, Hou J, Lee RJ, Flaherty KT, McArthur GA, Group B-S (2011) Improved survival with vemurafenib in melanoma with BRAF V600E mutation N Engl J Med 364:2507-2516. doi: 10.1056/NEJMoa1 103782

36. Rasche L, Angtuaco E, McDonald JE, Buros A, Stein C, Pawlyn C, Thanendrarajan S, Schinke C, Samant R, Yaccoby S, Walker BA, Epstein J, Zangari M, van Rhee F, Meissner T, Goldschmidt H, Hemminki K, Houlston R, Barlogie B, Davies FE, Morgan GJ, Weinhold N (2017) Low expression of hexokinase-2 is associated with false-negative FDG-positron emission tomography in multiple myeloma Blood 130:30-34. doi: 10.1182/blood-2017-03-774422

37. Nonomura Y, Yasumoto M, Yoshimura R, Haraguchi K, Ito S, Akashi T, Ohashi I (2001) Relationship between bone marrow cellularity and apparent diffusion coefficient J Magn Reson Imaging 13:757-760. doi: 10.1002/jmri.1105

38. Tsuji K, Kishi S, Tsuchida T, Yamauchi T, Ikegaya S, Urasaki Y, Fujiwara Y, Ueda T, Okazawa H, Kimura H (2015) Evaluation of staging and early response to chemotherapy with whole-body diffusion-weighted MRI in malignant lymphoma patients: A comparison with FDG-PET/CT J Magn Reson Imaging 41:1601-1607. doi: 10.1002/jmri.24714

39. Regacini R, Puchnick A, Shigueoka DC, Iared W, Lederman HM (2015) Whole-body diffusion-weighted magnetic resonance imaging versus FDG-PET/CT for initial lymphoma staging: systematic review on diagnostic test accuracy studies Sao Paulo Med J 133:141-150. doi: 10.1590/1516-3180.2014.8312810

40. Zhang J, Cui LB, Tang X, Ren XL, Shi JR, Yang HN, Zhang Y, Li ZK, Wu CG, Jian W, Zhao F, Ti XY, Yin H (2014) DW MRI at 3.0 T versus FDG PET/CT for detection of malignant pulmonary tumors Int J Cancer 134:606-611. doi: 10.1002/ijc.28394

41. Zamagni E, Patriarca F, Nanni C, Zannetti B, Englaro E, Pezzi A, Tacchetti P, Buttignol S, Perrone G, Brioli A, Pantani L, Terragna C, Carobolante F, Baccarani M, Fanin R, Fanti S, Cavo M (2011) Prognostic relevance of 18-F FDG PET/CT in newly diagnosed multiple myeloma patients treated with up-front autologous transplantation Blood 118:5989-5995. doi: 10.1182/blood-2011-06-361386 
Schürch et al.

42. Bartel TB, Haessler J, Brown TL, Shaughnessy JD, Jr., van Rhee F, Anaissie E, Alpe T, Angtuaco E, Walker R, Epstein J, Crowley J, Barlogie B (2009) F18-

fluorodeoxyglucose positron emission tomography in the context of other imaging techniques and prognostic factors in multiple myeloma Blood 114:2068-2076. doi: 10.1182/blood-2009-03-213280

43. Usmani SZ, Mitchell A, Waheed S, Crowley J, Hoering A, Petty N, Brown T, Bartel T, Anaissie E, van Rhee F, Barlogie B (2013) Prognostic implications of serial 18fluoro-deoxyglucose emission tomography in multiple myeloma treated with total therapy 3 Blood 121:1819-1823. doi: 10.1182/blood-2012-08-451690

44. Waheed S, Mitchell A, Usmani S, Epstein J, Yaccoby S, Nair B, van Hemert R, Angtuaco E, Brown T, Bartel T, McDonald J, Anaissie E, van Rhee F, Crowley J, Barlogie B (2013) Standard and novel imaging methods for multiple myeloma: correlates with prognostic laboratory variables including gene expression profiling data Haematologica 98:71-78. doi: 10.3324/haematol.2012.066555

45. Usmani SZ, Heuck C, Mitchell A, Szymonifka J, Nair B, Hoering A, Alsayed Y, Waheed S, Haider S, Restrepo A, Van Rhee F, Crowley J, Barlogie B (2012) Extramedullary disease portends poor prognosis in multiple myeloma and is overrepresented in high-risk disease even in the era of novel agents Haematologica 97:1761-1767. doi: 10.3324/haematol.2012.065698

46. Rasche L, Angtuaco EJ, Alpe TL, Gershner GH, McDonald JE, Samant RS, Kumar M, Van Hemert R, Epstein J, Deshpande S, Tytarenko R, Yaccoby S, Hillengass J, Thanendrarajan S, Schinke C, van Rhee F, Zangari M, Walker BA, Barlogie B, Morgan GJ, Davies FE, Weinhold N (2018) The presence of large focal lesions is a strong independent prognostic factor in multiple myeloma Blood 132:59-66. doi: 10.1182/blood-2018-04-842880

47. Abe Y, Narita K, Kobayashi H, Kitadate A, Takeuchi M, Ouchi T, Matsue K (2018) Prognostic Relevance of Medullary Abnormalities in the Appendicular Skeleton Detected By Positron Emission Tomography-Computed Tomography in Patients with Newly Diagnosed Multiple Myeloma Blood 132:1878-1878. doi: 10.1182/blood2018-99-110062

48. Moreau P, Attal M, Caillot D, Macro M, Karlin L, Garderet L, Facon T, Benboubker L, Escoffre-Barbe M, Stoppa AM, Laribi K, Hulin C, Perrot A, Marit G, Eveillard JR, Caillon F, Bodet-Milin C, Pegourie B, Dorvaux V, Chaleteix C, Anderson K, Richardson P, Munshi NC, Avet-Loiseau H, Gaultier A, Nguyen JM, Dupas B, Frampas E, Kraeber-Bodere F (2017) Prospective Evaluation of Magnetic Resonance Imaging and [(18)F]Fluorodeoxyglucose Positron Emission Tomography-Computed Tomography at Diagnosis and Before Maintenance Therapy in Symptomatic Patients With Multiple Myeloma Included in the IFM/DFCI 2009 Trial: Results of the IMAJEM Study J Clin Oncol 35:2911-2918. doi: 10.1200/JCO.2017.72.2975

49. Rasche L, Alapat D, Kumar M, Gershner G, McDonald J, Wardell CP, Samant R, Van Hemert R, Epstein J, Williams AF, Thanendrarajan S, Schinke C, Bauer M, Ashby C, Tytarenko RG, van Rhee F, Walker BA, Zangari M, Barlogie B, Davies FE, Morgan GJ, Weinhold N (2018) Combination of flow cytometry and functional imaging for monitoring of residual disease in myeloma Leukemia. doi: 10.1038/s41375-018-03290 
Schürch et al.

50. Rasche L, Kumar M, Gershner G, Samant R, Van Hemert R, Heidemeier A, Lapa C, Bley T, Buck A, McDonald J, Hillengass J, Epstein J, Thanendrarajan S, Schinke C, van Rhee F, Zangari M, Barlogie B, Davies FE, Morgan GJ, Weinhold N (2019) Lack of Spleen Signal on Diffusion Weighted MRI is associated with High Tumor Burden and Poor Prognosis in Multiple Myeloma: A Link to Extramedullary Hematopoiesis? Theranostics 9:4756-4763. doi: 10.7150/thno.33289

51. Zhou H, Neelakantan D, Ford HL (2017) Clonal cooperativity in heterogenous cancers Semin Cell Dev Biol 64:79-89. doi: 10.1016/j.semcdb.2016.08.028

52. Schürch CM, Federmann B, Quintanilla-Martinez L, Fend F (2018) Tumor Heterogeneity in Lymphomas: A Different Breed Pathobiology 85:130-145. doi: $10.1159 / 000475530$

53. Tricot $\mathrm{G}$ (2000) New insights into role of microenvironment in multiple myeloma Lancet 355:248-250. doi: 10.1016/S0140-6736(00)00019-2

54. Kuehl WM, Bergsagel PL (2002) Multiple myeloma: evolving genetic events and host interactions Nat Rev Cancer 2:175-187. doi: 10.1038/nrc746

55. Ribatti D, Nico B, Vacca A (2006) Importance of the bone marrow microenvironment in inducing the angiogenic response in multiple myeloma Oncogene 25:4257-4266. doi: $10.1038 /$ sj.onc. 1209456

56. Kawano Y, Moschetta M, Manier S, Glavey S, Gorgun GT, Roccaro AM, Anderson KC, Ghobrial IM (2015) Targeting the bone marrow microenvironment in multiple myeloma Immunol Rev 263:160-172. doi: 10.1111/imr.12233

57. Mitsiades CS, Mitsiades NS, Munshi NC, Richardson PG, Anderson KC (2006) The role of the bone microenvironment in the pathophysiology and therapeutic management of multiple myeloma: interplay of growth factors, their receptors and stromal interactions Eur J Cancer 42:1564-1573. doi: 10.1016/j.ejca.2005.12.025

58. Riether C, Schürch CM, Ochsenbein AF (2015) Regulation of hematopoietic and leukemic stem cells by the immune system Cell Death Differ 22:187-198. doi: 10.1038/cdd.2014.89

59. Sivaraj KK, Adams RH (2016) Blood vessel formation and function in bone Development 143:2706-2715. doi: 10.1242/dev.136861

60. Pratt G, Goodyear O, Moss P (2007) Immunodeficiency and immunotherapy in multiple myeloma Br J Haematol 138:563-579. doi: 10.1111/j.1365-

2141.2007.06705.x

61. De Bruyne E, Menu E, Van Valckenborgh E, De Raeve H, Van Camp B, Van Riet I, Vanderkerken K (2007) Myeloma cells and their interactions with the bone marrow endothelial cells Current Immunology Reviews 3:41-55

62. Wang J, De Veirman K, Faict S, Frassanito MA, Ribatti D, Vacca A, Menu E (2016) Multiple myeloma exosomes establish a favourable bone marrow microenvironment with enhanced angiogenesis and immunosuppression J Pathol 239:162-173. doi: $10.1002 /$ path.4712 
Schürch et al.

63. Nakamura K, Kassem S, Cleynen A, Chretien ML, Guillerey C, Putz EM, Bald T, Forster I, Vuckovic S, Hill GR, Masters SL, Chesi M, Bergsagel PL, Avet-Loiseau H, Martinet L, Smyth MJ (2018) Dysregulated IL-18 Is a Key Driver of Immunosuppression and a Possible Therapeutic Target in the Multiple Myeloma Microenvironment Cancer cell 33:634-648 e635. doi: 10.1016/j.ccell.2018.02.007

64. Gorgun GT, Whitehill G, Anderson JL, Hideshima T, Maguire C, Laubach J, Raje N, Munshi NC, Richardson PG, Anderson KC (2013) Tumor-promoting immunesuppressive myeloid-derived suppressor cells in the multiple myeloma microenvironment in humans Blood 121:2975-2987. doi: 10.1182/blood-2012-08448548

65. Frenquelli M, Caridi N, Antonini E, Storti F, Vigano V, Gaviraghi M, Occhionorelli M, Bianchessi S, Bongiovanni L, Spinelli A, Marcatti M, Belloni D, Ferrero E, Karki S, Brambilla P, Martinelli-Boneschi F, Colla S, Ponzoni M, DePinho RA, Tonon G (2019) The WNT receptor ROR2 drives the interaction of multiple myeloma cells with the microenvironment through AKT activation Leukemia. doi: 10.1038/s41375-0190486-9

66. An G, Acharya C, Feng X, Wen K, Zhong M, Zhang L, Munshi NC, Qiu L, Tai YT, Anderson KC (2016) Osteoclasts promote immune suppressive microenvironment in multiple myeloma: therapeutic implication Blood 128:1590-1603. doi: 10.1182/blood2016-03-707547

67. Karadag A, Oyajobi BO, Apperley JF, Russell RG, Croucher PI (2000) Human myeloma cells promote the production of interleukin 6 by primary human osteoblasts Br J Haematol 108:383-390. doi: 10.1046/j.1365-2141.2000.01845.x

68. Chauhan D, Singh AV, Brahmandam M, Carrasco R, Bandi M, Hideshima T, Bianchi G, Podar K, Tai YT, Mitsiades C, Raje N, Jaye DL, Kumar SK, Richardson P, Munshi N, Anderson KC (2009) Functional interaction of plasmacytoid dendritic cells with multiple myeloma cells: a therapeutic target Cancer cell 16:309-323. doi: 10.1016/j.ccr.2009.08.019

69. Zheng Y, Cai Z, Wang S, Zhang X, Qian J, Hong S, Li H, Wang M, Yang J, Yi Q (2009) Macrophages are an abundant component of myeloma microenvironment and protect myeloma cells from chemotherapy drug-induced apoptosis Blood 114:36253628. doi: 10.1182/blood-2009-05-220285

70. Azab AK, Runnels JM, Pitsillides C, Moreau AS, Azab F, Leleu X, Jia X, Wright R, Ospina B, Carlson AL, Alt C, Burwick N, Roccaro AM, Ngo HT, Farag M, Melhem MR, Sacco A, Munshi NC, Hideshima T, Rollins BJ, Anderson KC, Kung AL, Lin CP, Ghobrial IM (2009) CXCR4 inhibitor AMD3100 disrupts the interaction of multiple myeloma cells with the bone marrow microenvironment and enhances their sensitivity to therapy Blood 113:4341-4351. doi: 10.1182/blood-2008-10-186668

71. Stadtmauer EA, Pasquini MC, Blackwell B, Hari P, Bashey A, Devine S, Efebera Y, Ganguly S, Gasparetto C, Geller N, Horowitz MM, Koreth J, Knust K, Landau H, Brunstein C, McCarthy P, Nelson C, Qazilbash MH, Shah N, Vesole DH, Vij R, Vogl DT, Giralt S, Somlo G, Krishnan A (2019) Autologous Transplantation, Consolidation, and Maintenance Therapy in Multiple Myeloma: Results of the BMT CTN 0702 Trial J Clin Oncol 37:589-597. doi: 10.1200/JCO.18.00685 
Schürch et al.

72. Barlogie B, Mitchell A, van Rhee F, Epstein J, Morgan GJ, Crowley J (2014) Curing myeloma at last: defining criteria and providing the evidence Blood 124:3043-3051. doi: 10.1182/blood-2014-07-552059

73. Mateos MV, Dimopoulos MA, Cavo M, Suzuki K, Jakubowiak A, Knop S, Doyen C, Lucio P, Nagy Z, Kaplan P, Pour L, Cook M, Grosicki S, Crepaldi A, Liberati AM, Campbell P, Shelekhova T, Yoon SS, Iosava G, Fujisaki T, Garg M, Chiu C, Wang J, Carson R, Crist W, Deraedt W, Nguyen H, Qi M, San-Miguel J, Investigators AT (2018) Daratumumab plus Bortezomib, Melphalan, and Prednisone for Untreated Myeloma N Engl J Med 378:518-528. doi: 10.1056/NEJMoa1714678

74. Facon T, Kumar S, Plesner T, Orlowski RZ, Moreau P, Bahlis N, Basu S, Nahi H, Hulin C, Quach H, Goldschmidt H, O'Dwyer M, Perrot A, Venner CP, Weisel K, Mace JR, Raje N, Attal M, Tiab M, Macro M, Frenzel L, Leleu X, Ahmadi T, Chiu C, Wang J, Van Rampelbergh R, Uhlar CM, Kobos R, Qi M, Usmani SZ, Investigators MT (2019) Daratumumab plus Lenalidomide and Dexamethasone for Untreated Myeloma N Engl J Med 380:2104-2115. doi: 10.1056/NEJMoa1817249

75. Jethava Y, Mitchell A, Zangari M, Waheed S, Schinke C, Thanendrarajan S, Sawyer J, Alapat D, Tian E, Stein C, Khan R, Heuck CJ, Petty N, Avery D, Steward D, Smith R, Bailey C, Epstein J, Yaccoby S, Hoering A, Crowley J, Morgan G, Barlogie B, van Rhee F (2016) Dose-dense and less dose-intense Total Therapy 5 for gene expression profiling-defined high-risk multiple myeloma Blood Cancer J 6:e453. doi: $10.1038 / \mathrm{bcj} .2016 .64$

76. Jethava YS, Mitchell A, Epstein J, Zangari M, Yaccoby S, Tian E, Waheed S, Khan R, Papanikolaou X, Grazziutti M, Cottler-Fox M, Petty N, Steward D, Panozzo S, Bailey C, Hoering A, Crowley J, Sawyer J, Morgan G, Barlogie B, van Rhee F (2016) Adverse Metaphase Cytogenetics Can Be Overcome by Adding Bortezomib and Thalidomide to Fractionated Melphalan Transplants Clin Cancer Res. doi: 10.1158/1078-0432.CCR-15-2620

77. Cavo M, Goldschmidt H, Rosinol L, Pantani L, Zweegman S, Salwender HJ, Lahuerta JJ, Lokhorst HM, Petrucci MT, Blau I, Oriol A, Testoni N, Weisel K, Rios R, Patriarca F, Blanchard J, Dozza L, Mateos MV, Galli M, San-Miguel JF, Boccadoro M, Blade J, Sonneveld P (2018) Double Vs Single Autologous Stem Cell Transplantation for Newly Diagnosed Multiple Myeloma: Long-Term Follow-up (10Years) Analysis of Randomized Phase 3 Studies Blood 132. doi: 10.1182/blood-201899-112899

78. Kumar S, Kaufman JL, Gasparetto C, Mikhael J, Vij R, Pegourie B, Benboubker L, Facon T, Amiot M, Moreau P, Punnoose EA, Alzate S, Dunbar M, Xu T, Agarwal SK, Enschede SH, Leverson JD, Ross JA, Maciag PC, Verdugo M, Touzeau C (2017) Efficacy of venetoclax as targeted therapy for relapsed/refractory $t(11 ; 14)$ multiple myeloma Blood 130:2401-2409. doi: 10.1182/blood-2017-06-788786

79. Moreau P, Chanan-Khan A, Roberts AW, Agarwal AB, Facon T, Kumar S, Touzeau C, Punnoose EA, Cordero J, Munasinghe W, Jia J, Salem AH, Freise KJ, Leverson JD, Enschede SH, Ross JA, Maciag PC, Verdugo M, Harrison SJ (2017) Promising efficacy and acceptable safety of venetoclax plus bortezomib and dexamethasone in relapsed/refractory MM Blood 130:2392-2400. doi: 10.1182/blood-2017-06-788323 
Schürch et al.

80. Kortum KM, Einsele H (2017) First targeted therapy in multiple myeloma Blood 130:2359-2360. doi: 10.1182/blood-2017-09-805341

81. National Comprehensive Cancer Network: Multiple Myeloma (Version 2.2020). https://www.nccn.org/professionals/physician_gls/PDF/myeloma.pdf. Accessed 25.10.2019

82. Avet-Loiseau H, Leleu X, Roussel M, Moreau P, Guerin-Charbonnel C, Caillot D, Marit G, Benboubker L, Voillat L, Mathiot C, Kolb B, Macro M, Campion L, Wetterwald M, Stoppa AM, Hulin C, Facon T, Attal M, Minvielle S, Harousseau JL (2010) Bortezomib plus dexamethasone induction improves outcome of patients with $\mathrm{t}(4 ; 14)$ myeloma but not outcome of patients with del(17p) J Clin Oncol 28:46304634. doi: 10.1200/JCO.2010.28.3945

83. Andrulis M, Lehners N, Capper D, Penzel R, Heining C, Huellein J, Zenz T, von Deimling A, Schirmacher P, Ho AD, Goldschmidt H, Neben K, Raab MS (2013) Targeting the BRAF V600E mutation in multiple myeloma Cancer Discov 3:862-869. doi: 10.1158/2159-8290.CD-13-0014

84. Sharman JP, Chmielecki J, Morosini D, Palmer GA, Ross JS, Stephens PJ, Stafl J, Miller VA, Ali SM (2014) Vemurafenib response in 2 patients with posttransplant refractory BRAF V600E-mutated multiple myeloma Clin Lymphoma Myeloma Leuk 14:e161-163. doi: 10.1016/j.clml.2014.06.004

85. Heuck CJ, Jethava Y, Khan R, van Rhee F, Zangari M, Chavan S, Robbins K, Miller SE, Matin A, Mohan M, Ali SM, Stephens PJ, Ross JS, Miller VA, Davies F, Barlogie $B$, Morgan G (2016) Inhibiting MEK in MAPK pathway-activated myeloma Leukemia 30:976-980. doi: 10.1038/leu.2015.208

86. Weinhold N, Ashby C, Rasche L, Chavan SS, Stein C, Stephens OW, Tytarenko R, Bauer MA, Meissner T, Deshpande S, Patel PH, Buzder T, Molnar G, Peterson EA, van Rhee F, Zangari M, Thanendrarajan S, Schinke C, Tian E, Epstein J, Barlogie B, Davies FE, Heuck CJ, Walker BA, Morgan GJ (2016) Clonal selection and double-hit events involving tumor suppressor genes underlie relapse in myeloma Blood 128:1735-1744. doi: 10.1182/blood-2016-06-723007

87. Lohr JG, Stojanov P, Carter SL, Cruz-Gordillo P, Lawrence MS, Auclair D, Sougnez C, Knoechel B, Gould J, Saksena G, Cibulskis K, McKenna A, Chapman MA, Straussman R, Levy J, Perkins LM, Keats JJ, Schumacher SE, Rosenberg M, Multiple Myeloma Research C, Getz G, Golub TR (2014) Widespread genetic heterogeneity in multiple myeloma: implications for targeted therapy Cancer Cell 25:91-101. doi: 10.1016/j.ccr.2013.12.015

88. Rajkumar SV, Dimopoulos MA, Palumbo A, Blade J, Merlini G, Mateos MV, Kumar S, Hillengass J, Kastritis E, Richardson P, Landgren O, Paiva B, Dispenzieri A, Weiss B, LeLeu X, Zweegman S, Lonial S, Rosinol L, Zamagni E, Jagannath S, Sezer O, Kristinsson SY, Caers J, Usmani SZ, Lahuerta JJ, Johnsen HE, Beksac M, Cavo M, Goldschmidt H, Terpos E, Kyle RA, Anderson KC, Durie BG, Miguel JF (2014) International Myeloma Working Group updated criteria for the diagnosis of multiple myeloma Lancet Oncol 15:e538-548. doi: 10.1016/S1470-2045(14)70442-5 
Schürch et al.

89. Rajkumar SV (2016) Multiple myeloma: 2016 update on diagnosis, risk-stratification, and management Am J Hematol 91:719-734. doi: 10.1002/ajh.24402

90. Avet-Loiseau H, Malard F, Campion L, Magrangeas F, Sebban C, Lioure B, Decaux O, Lamy T, Legros L, Fuzibet JG, Michallet M, Corront B, Lenain P, Hulin C, Mathiot C, Attal M, Facon T, Harousseau JL, Minvielle S, Moreau P, Intergroupe Francophone du M (2011) Translocation $\mathrm{t}(14 ; 16)$ and multiple myeloma: is it really an independent prognostic factor? Blood 117:2009-2011. doi: 10.1182/blood-2010-07295105

91. Walker BA, Wardell CP, Murison A, Boyle EM, Begum DB, Dahir NM, Proszek PZ, Melchor L, Pawlyn C, Kaiser MF, Johnson DC, Qiang YW, Jones JR, Cairns DA, Gregory WM, Owen RG, Cook G, Drayson MT, Jackson GH, Davies FE, Morgan GJ (2015) APOBEC family mutational signatures are associated with poor prognosis translocations in multiple myeloma Nat Commun 6:6997. doi: 10.1038/ncomms7997

92. Gomez-Bougie P, Maiga S, Tessoulin B, Bourcier J, Bonnet A, Rodriguez MS, Le Gouill S, Touzeau C, Moreau P, Pellat-Deceunynck C, Amiot M (2018) BH3-mimetic toolkit guides the respective use of BCL2 and MCL1 BH3-mimetics in myeloma treatment Blood 132:2656-2669. doi: 10.1182/blood-2018-03-836718

93. Teoh PJ, An O, Chung TH, Chooi JY, Toh SHM, Fan S, Wang W, Koh BTH, Fullwood MJ, Ooi MG, de Mel S, Soekojo CY, Chen L, Ng SB, Yang H, Chng WJ (2018) Aberrant hyperediting of the myeloma transcriptome by ADAR1 confers oncogenicity and is a marker of poor prognosis Blood 132:1304-1317. doi: 10.1182/blood-2018-02-832576

94. Ishizuka JJ, Manguso RT, Cheruiyot CK, Bi K, Panda A, Iracheta-Vellve A, Miller BC, Du PP, Yates KB, Dubrot J, Buchumenski I, Comstock DE, Brown FD, Ayer A, Kohnle IC, Pope HW, Zimmer MD, Sen DR, Lane-Reticker SK, Robitschek EJ, Griffin GK, Collins NB, Long AH, Doench JG, Kozono D, Levanon EY, Haining WN (2019) Loss of ADAR1 in tumours overcomes resistance to immune checkpoint blockade Nature 565:43-48. doi: 10.1038/s41586-018-0768-9

95. Venkata JK, An N, Stuart R, Costa LJ, Cai H, Coker W, Song JH, Gibbs K, Matson T, Garrett-Mayer E, Wan Z, Ogretmen B, Smith C, Kang Y (2014) Inhibition of sphingosine kinase 2 downregulates the expression of c-Myc and Mcl-1 and induces apoptosis in multiple myeloma Blood 124:1915-1925. doi: 10.1182/blood-2014-03559385 
Schürch et al.

\section{Figures}

Figure 1

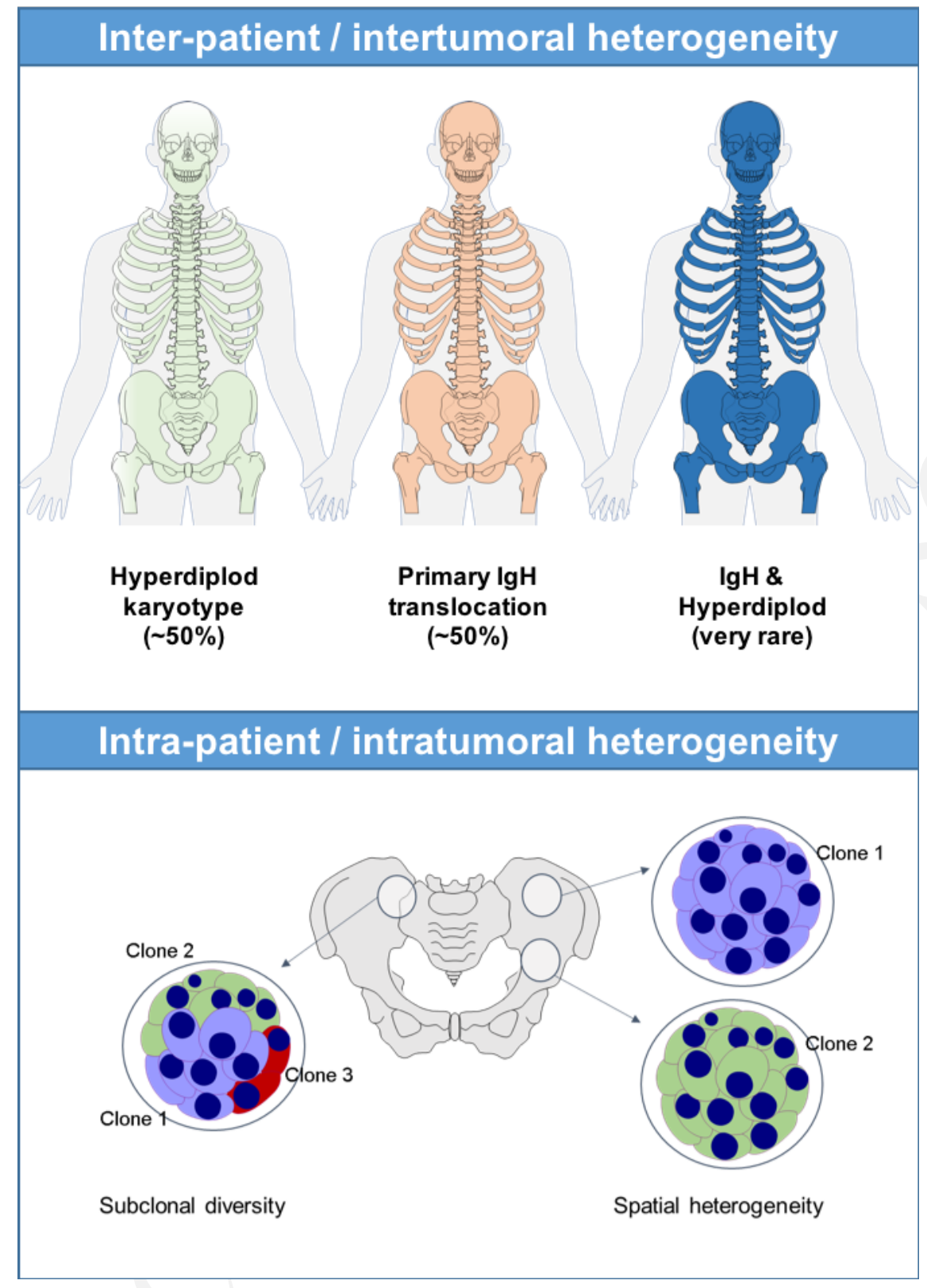


Schürch et al.

Figure 2
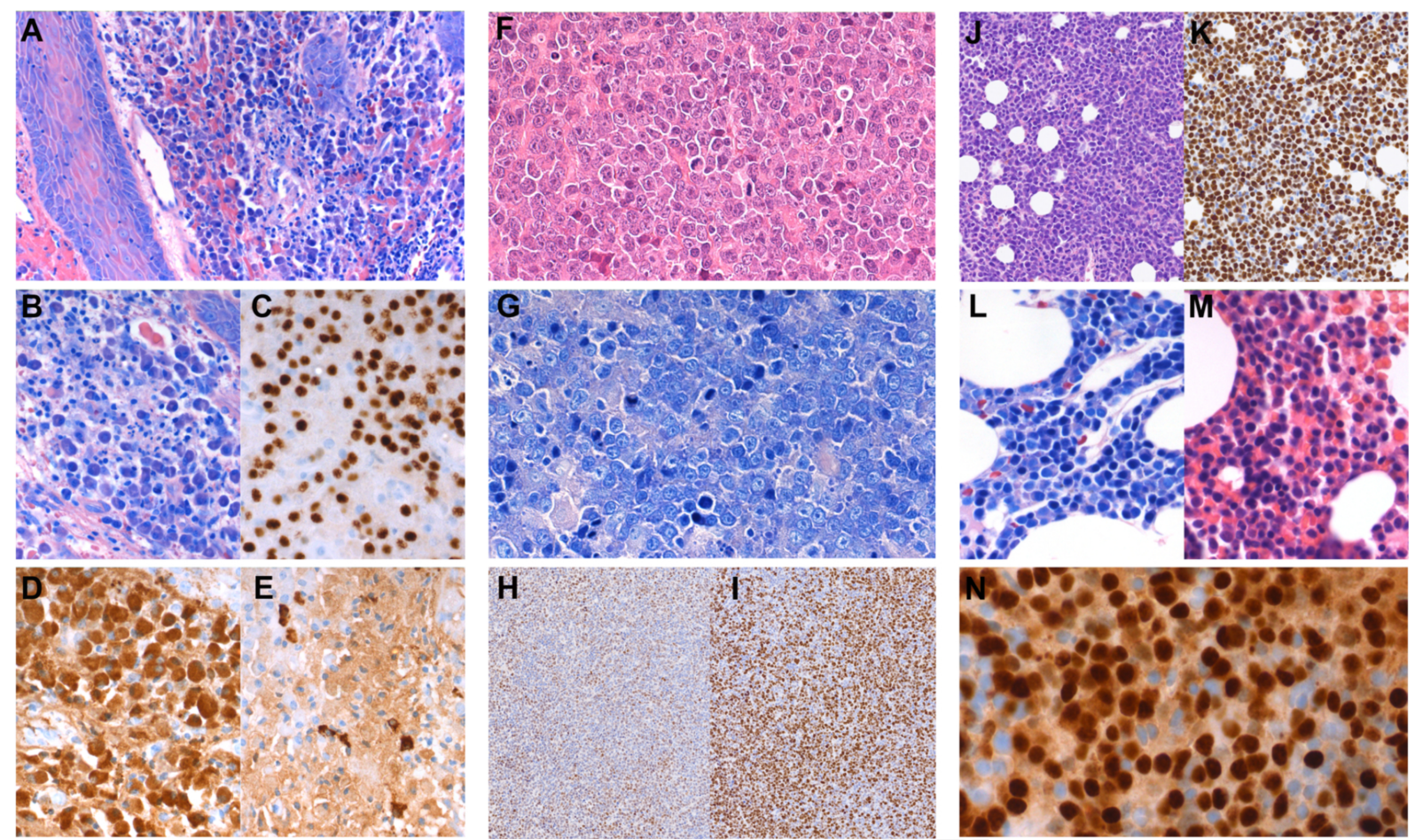
Schürch et al.

Figure 3

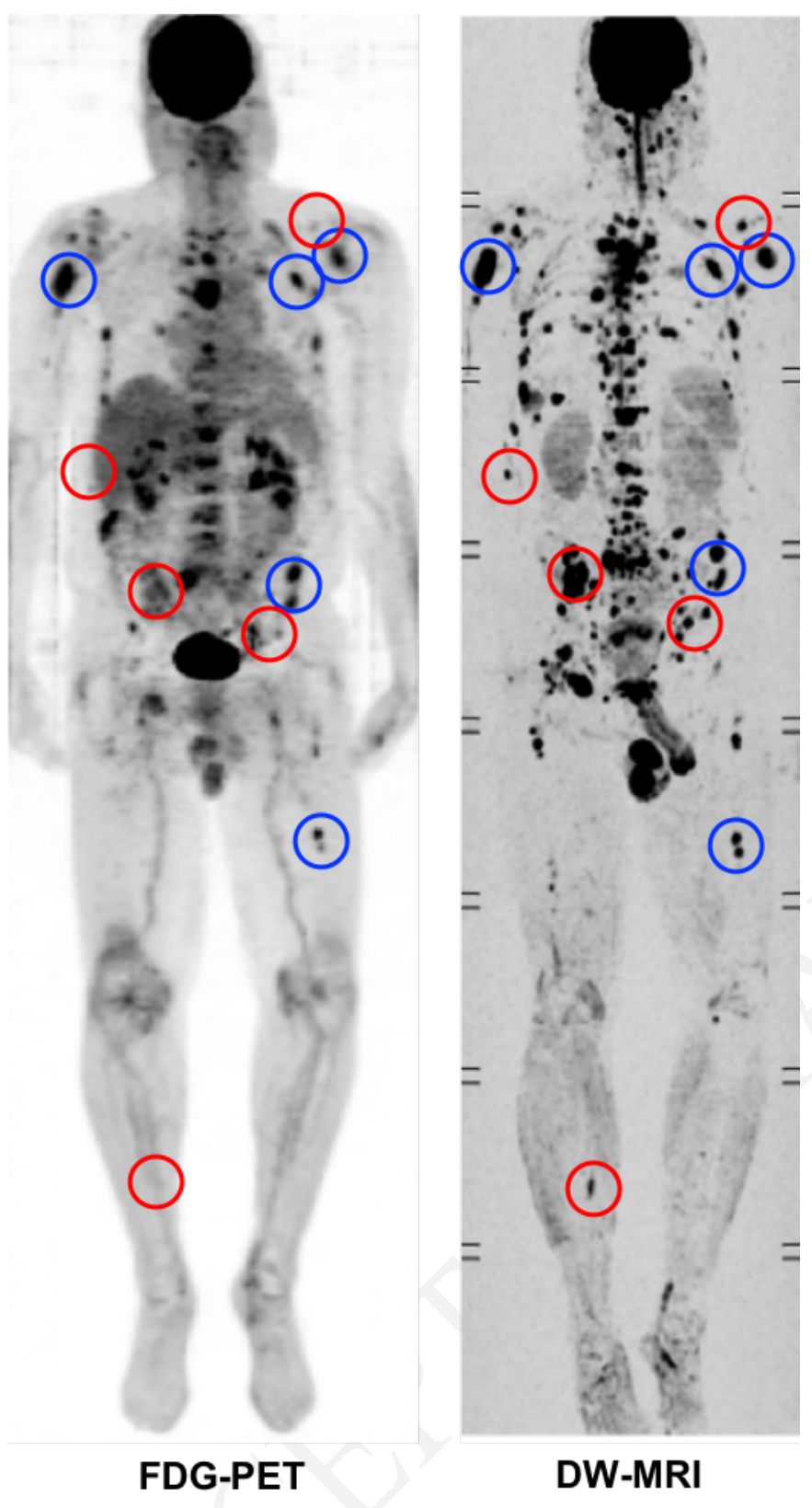


Schürch et al.

Figure 4

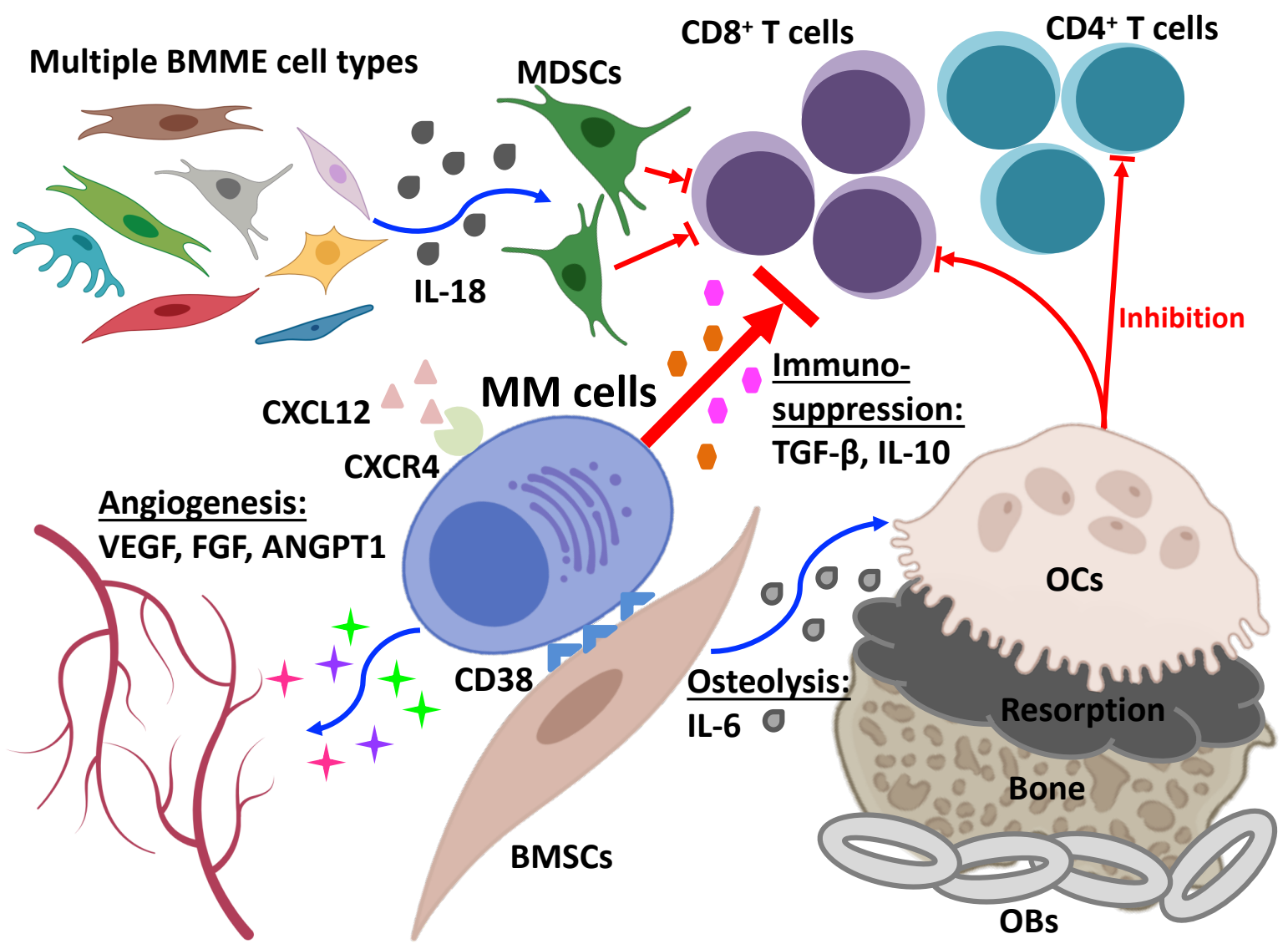

